Original Article

\title{
Knowledge of Sexual Harassment among the Undergraduate students in Udupi district
}

\author{
Aditi Gurung $^{1}$, Sangeetha Priyadarshini ${ }^{2} \&$ Binu M argaret E. ${ }^{3}$ \\ ${ }^{1}$ M .Sc Nursing, ${ }^{2,3}$ Assistant Professors, ${ }^{1,2,3}$ Department of Child Health Nursing \\ M anipal College of Nursing, M anipal University, M anipal.
}

*Corresponding Author : Sangeetha Priyadarshini, Assistant Professor, Department of Child Health Nursing, Manipal College of Nursing, Manipal University, Manipal. Mobile : +919844896929 E-mail : Sangeetha.P@manipal.edu

Received : :08-03-2015

Review Completed : 15-10-2015

Accepted : :23-03-2016

Keywords : knowledge, sexual harassment, undergraduate students

\begin{tabular}{|c|}
\hline Access this article online \\
\hline Quick Response Code \\
\hline
\end{tabular}

Abstract :

Introduction : Sexual harassment is a problem that is concerned with public health and has a serious effects on the students' dignity, physical as well as mental health. Knowledge on Sexual harassment equips the students to face such situation courageously.

Objectives : The objective of the study was to assess the knowledge of the undergraduate students on sexual harassment.

Methods : A cross- sectional survey was conducted among 408 undergraduate students of selected professional colleges of Udupi district. Data was collected using structured knowledge questionnaire on sexual harassment. Stratified proportionate systematic random sampling technique was used.

Result: The study found that $82.4 \%$ of the students had average knowledge, $13.2 \%$ had good knowledge and $4.4 \%$ had poor knowledge on sexual harassment.

Conclusion : This study shows that students have average knowledge on sexual harassment which shows that they need further education that may help them to take proper actions if harassment ever occur.

\section{Introduction}

According to ministry of law and justice of India (2013) ${ }^{1}$, sexual harassment includes any one or more of the following unwelcome acts or behaviour namely,

- sexual contact or advances; or

- a demand or request for sexual favours; or

- making sexually coloured remarks; or

- showingpornography; or

- Any other unwelcome physical, verbal or non-verbal conduct of sexual nature.

In simple words, sexual harassment means the sexual advances, requests for sexual favours, and other verbal, non-verbal or physical conduct of sexual in nature by the person of opposite sex or same sex, whether intentional or not, and which is regarded as undesired or forced.

In the last few decades, the crime against women in India has increased by 6.4 percent in 2012 from the previous year. ${ }^{2}$ Karnataka has an incidence of 10366 which accounts for $4.24 \%$ of the total incidence in the country. Out of this, 1621 were the cases of rape which was found to be the highest in the age group 18-30 years. ${ }^{3}$ Sexual harassment is irrespective of gender that means a person can be sexually harassed by another individual of different or even that of the same gender. But in all the cases of harassment, female is found to be the victim and male is found to be the perpetrator while it is very well known that even the males get sexually harassed. But the reason for not being reported is worth investigating.

M any studies have revealed that the students irrespective of their gender get sexually harassed in the colleges by their colleagues, senior students and faculty members. Despite of the sexual harassment committees prevailing in the colleges to address such issues, most of the time these incidents are not being reported. It may be because of the 
lack of awareness regarding sexual harassment, due to which the victims may not be aware of the fact that they are actually being sexually harassed. ${ }^{10,11}$

A descriptive cross sectional study was done in Nigeria to assess the experience of sexual harassment among the students of School of Nursing. The study found that $58 \%$ of respondents ( $20.0 \%$ males, $80.0 \%$ females) had ever been sexually harassed. Types of Sexual Harassment experienced were unwanted body contact (79.3\%), breast contact $(67.6 \%)$, enticement $(45.5 \%)$, attempted rape (39.3\%) and unwanted kiss (26.3\%). ${ }^{4}$

According to a survey conducted by the Justice department of US in 2006-2010 it was found that the victims of sexual assault had three times more risk to suffer from depression, six times more risk to suffer from posttraumatic stress disorder, 13 times more risk to abuse alcohol, 26 times more risk to abuse drugs and four times more risk for suicidal ideations. ${ }^{5}$

Hence it is very evident that the incidence of sexual harassment is rising. The incidence peaks between the ages of 12-34 yrs. It has a detrimental effect in ones' life. Therefore, it is very important to assess the student's knowledge regarding sexual harassment and provide necessary interventions.

\section{Materials and Methods}

A cross- sectional study was done to assess the knowledge of sexual harassment among undergraduate students. The total calculated sample size was 420 including five percentage of the non- respondents. Sample size was calculated by using the formula mentioned below:

$\mathbf{n}=$ required sample size

$$
n=\frac{t^{2} \times p(1-p)}{d^{2}}
$$

$\mathbf{t}=$ confidence level at $95 \%$ (standard value of 1.96)

$\mathbf{p}=$ estimated proportion (ten percentage) based on pilot study result.

$\mathbf{d}=$ allowable error $3 \%$ (standard value of 0.03 )

The sample size was estimated to be 385 and by rounding off the sample size was found to be 400 . Further, $5 \%$ non- respondents was added which was 20 . So the final sample size was found to be 420 .

The population was the undergraduate students of the selected professional colleges of Udupi district. Proportionate stratified systematic random sampling was used to select students in the selected colleges from Udupi district.

There were total 14 institutions among which 12 institutions offered undergraduate programs. Among the 12 institutions, eight institutions were selected randomly by chit method. The total population of the eight institutions excluding the $1^{\text {st }}$ year was 7253 and the sample requirement was 420 . Hence the proportion of the student strength was calculated for each institution and the same proportion was used to take the samples from each institution. Same method was used to take the samples from each class of the institution. The proportion of the student strength of each class i.e. $2^{\text {nd }}$ year, $3^{\text {rd }}$ year and $4^{\text {th }}$ (for four yr courses) or $2^{\text {nd }}$ year and $3^{\text {rd }}$ year (for 3 yr courses) was calculated and the same proportion was used to take the sample from the respective classes. For e.g. institution A has a total student strength of 63 which is $0.8 \%$ of the total 7253 population. Hence the same proportion is used to take the sample from the institution i.e. $0.8 \%$ of 420 which is 4 . The institution has a total strength of 63 students with 32 students in $2^{\text {nd }}$ yr class i.e. $50.8 \%$ of the total strength and $3^{\text {rd }} \mathrm{yr}$ has 31 students i.e. $49.2 \%$ of the total strength. The same proportion was used to take the samples from each class. From $2^{\text {nd }}$ year $50.8 \%$ of 4 which comes out to be 2 and $49.2 \%$ from $3^{\text {rd }}$ year $49.2 \%$ of 4 which comes out to be 2 . And finally these 4 samples from each class were taken through systematic random sampling method by using students' registration number. In case of $2^{\text {nd }}$ year, the class strength was $\mathrm{N}=32$ and the sample requirement was $n=2$. Hence sampling interval ' $k$ ' was calculated by dividing $K$ with $k$ ( $N / n$ i.e. $32 / 2$ ) which was found to be 16 . Then one number was randomly selected from one to 16 using the chit method and the student whose register number comes in the same serial number was selected as the first sample. For example student 
whose register number comes in serial number 8 is selected. For the selection of the next sample the value of $k$ was added to the first sample serial number was $16+$ ten which is found to be 24 . So the student whose register number came in serial number 24 was selected. The same method was used for all the other institutions. For the better statistical outcome, the eight colleges were grouped into two groupsi.e. technical and health sciences.

Administrative permission was taken from Head of Institution and the Institutional Ethics Committee. Informed consent was taken from the participants and confidentiality of the information was maintained.

Demographic proforma and structured knowledge questionnaire on sexual harassment were developed by the researcher. The demographic proforma had 9 items including age, sex, religion, native country, course and the year of course, percentage scored in the last exam, place of stay and source of information. The structured knowledge questionnaire on sexual harassment included the areas like: meaning, types, laws and policies, preventive and corrective measures and the effects of sexual harassment. The tool was divided into three sections: section $A$ and section B. Section A included the first 26 items which were multiple choice questions whereas section B included five items which were dichotomous in nature. Each item in section $A$ and section $B$ if answered correctly had a score of ' 1 ' and ' 0 ' for an incorrect answer. The score ranged from 0 31. The total score was then classified as poor knowledge, average knowledge and good knowledge with a score ranging between $0-10,11-21$ and 22-31 respectively.

The tools were pretested among 10 samples and the reliability was done among 20 samples. The reliability for section $A$ was determined by using the Spearman-Brown prediction formula via split half method. The reliability coefficient for section A was found to be 0.94 . The reliability for section B was calculated using Kuder Richardson formula which was found to be 0.75 . And the reliability for section $C$ was determined using test- retest method which was found to be 0.95 . Hence the tool II was found to be reliable.
Data was collected by distributing the questionnaires among the students of the selected colleges during their free hours and were clearly explained about the purpose of the study. Informed consent was obtained from the participants and the filled questionnaire forms were collected back. Among the 420 students, only 408 filled the questionnaire. The remaining 12 students did not wish to participate in the study.

After assessing the knowledge, an informational leaflet on Sexual Harassment was developed and distributed among the students to further enhance their knowledge.

\section{Results}

\section{Demographic Characteristics}

A total of 408 students participated in the study. Majority of the students $390(95.6 \%)$ belonged to the age group of 18-22 years, 223 (54.7\%) were males, 333 (81.6\%) were Hindus, 388 (95.1\%) were from India, 316 (77.5\%) were from technical course, $145(35.5 \%)$ were from $2^{\text {nd }} Y$ r. Bachelors, 132 (32.4\%) secured $71-80 \%$ in the last university exam, $333(81.6 \%)$ resided in the hostel and 343 (84.1\%) got the information from TV on sexual harassment.

\section{Knowledge on sexual harassment.}

The study found that majority of the undergraduate students 336 (82.4\%) had average knowledge, 54 (13.2\%) had good knowledge and $18(4.4 \%)$ had poor knowledge. In spite of the majority of the students having good knowledge, the study found that $250(61.3 \%)$ of the students were not aware of the provision of grievances committee pertaining to sexual harassment in their college.

The data presented in table 1 shows that the maximum possible score was 33 and the range was 22 . The mean and the standard deviation were found to be 17.6 and 3.59 respectively.

The data was further analyzed to assess the association between the knowledge on sexual harassment and gender. Chi- square test was used. The findings are shown in table 2. 
The findings in table 2 shows, that there is a significant association between knowledge on sexual harassment and the course of study $\left(?^{2}=7.040\right.$ and $\left.p=0.03 \mathrm{DF}, 2\right)$ at 0.05 level of significance. Whereas the findings in table 2 shows that there is no association between knowledge on sexual harassment and gender ( $?^{2}=1.064$ and $p=0.58$, DF 2 ) as well as there is no association between knowledge on sexual harassment and age $\left(?^{2}=4.97\right.$ and $p=0.083$, DF 2$)$ at 0.05 level of significance.
Table 1 : Range, M ean and Standard deviation of knowledge on sexual harassment

$n=408$

\begin{tabular}{|l|c|c|c|}
\hline Variable & Maximum score & Mean \pm SD & Range \\
\hline Knowledge score & 33 & $17.65 \pm 3.59$ & $27-5$ \\
\hline
\end{tabular}

Table 2 : Association between the knowledge on sexual harassment and the demographic variables

\begin{tabular}{|l|c|c|c|c|c|c|}
\hline Variables & $\begin{array}{c}\text { poor knowledge } \\
\text { frequency/\% }\end{array}$ & $\begin{array}{c}\text { Average knowledge } \\
\text { frequency/\% }\end{array}$ & $\begin{array}{c}\text { Good knowledge } \\
\text { frequency/\% }\end{array}$ & $\chi^{2}$ & df & p value \\
\hline Gender & 10 & & & & & \\
\hline - Male & $4.49 \%$ & $83.85 \%$ & $11.66 \%$ & & & \\
\hline & 8 & 149 & 28 & & & \\
\hline - Female & $4.32 \%$ & $80.54 \%$ & $15.13 \%$ & & & \\
\hline & & & & & & \\
\hline Age group in yrs. & 15 & 322 & 53 & 4.97 & 2 & 0.08 \\
\hline$\cdot 18-22$ & $3.85 \%$ & $82.56 \%$ & $13.59 \%$ & & & \\
\hline & 3 & 14 & 1 & & & \\
\hline$\cdot 23-27$ & $16.67 \%$ & $77.78 \%$ & $5.55 \%$ & & & \\
\hline & & & & & & \\
\hline Courses of study & 7 & 67 & 18 & 7.040 & 2 & $0.03 *$ \\
\hline$\cdot$ Health sciences & $(7.61 \%)$ & $(72.83 \%)$ & $(19.56 \%)$ & & & \\
\hline & 11 & 269 & 36 & & & \\
\hline$\cdot$ Technical & $(3.48 \%)$ & $(85.13 \%)$ & $(11.39 \%)$ & & & \\
\hline
\end{tabular}

\section{Discussion}

A cross-sectional study was conducted by $M$ enon $A$ et al in Zambia among 855 students of the University of Zambia, where 401 were male students and 422 were female students to determine the students' knowledge regarding sexual harassment. A systematic sampling was applied and self- administered questionnaire was used. The study revealed that sexual harassment existed in the university. Majority of the subjects (71.5\%) had knowledge about sexual harassment, whereas $5.8 \%$ did not have knowledge about sexual harassment. About $16 \%$ of the students were not sure about their knowledge on sexual harassment and $3 \%$ of the subjects did not responded to the questionnaire. There was no significant association between the gender and the knowledge about sexual harassment $(p=0.27)$. ${ }^{6}$ The present study found that majority of the undergraduate students 336 (82.4\%) had average knowledge, 54 (13.2\%) had good knowledge and 18 (4.4\%) had poor knowledge.

A cross-sectional study was conducted by Abeywardene A. et al in Sri Lanka among 242 schoolboys aged 14-19 years from two Colombo district schools to assess the knowledge on sexual harassment and sexual abuse. This study showed a high prevalence of sexual harassment in the schoolboys on par with global figures. The knowledge on sexual abuse was low and on sexual harassment it was extremely low. Only 3.7\% had knowledge on sexual harassment. ${ }^{7}$

Where as in the present study only $4.4 \%$ had poor knowledge on sexual harassment.

A survey was conducted by Johannes A in Mumbai, India among 890 undergraduate and postgraduate students and 66 faculty staffs. The main objectives of the study were to assess the awareness and how the students as well as the 
faculty members perceive sexual harassment. M ajority of the students too had very less knowledge about the definition of sexual harassment. About $39 \%$ of the students had no idea about the provisions for a women development cell situated in the university. ${ }^{8}$ Which is in contrast to the present study were only $4.4 \%$ had poor knowledge on sexual harassment

A descriptive survey was conducted by Susan $\mathrm{K}$ et al in America among 588 metropolitan high school students with equal number of male and female students. The samples differed in size, race, location and socioeconomic background. The main objective of the study was to assess the knowledge and attitude regarding sexual harassment, sexual abuse and rape. The Kruskal- Wallis one-way analysis was used to assess the differences between male and female responses which showed that the female students had more knowledge regarding sexual harassment than compared to male students. ${ }^{9}$ in contrast the present study shows no association between knowledge on sexual harassment and gender $\left(?^{2}=1.064\right.$ and $p=0.58, d f 2$ ). The overall results show that the level of sexual harassment awareness amongst the students is average. In view of globalization and the diversity of life style, the sexual harassment issues faced are immense. Organizations have a central role in ensuring that students have adequate level of awareness, knowledge and skills to handle situations so that they can protect themselves. Thus, students need to understand the predominant situations of sexual harassment existed today in order to

\section{References}

1. http://www.odisha.gov.in/schooleducation/Sexual_Harassment at_workplace_ACT_2013.

2. Bhalla. N. Reports of rape, dowry deaths, molestation rise in India in 2012 [online]. 2013 J un 14 [cited on 2013 Aug 16]; Available from: URL: http:// in.reuters.com/article/2013/06/14/india-rape-women-2012report-idINDEE95D0B920130614

3. National Crime Record Bureau. [Online]. 2012 [cited on 2013 Aug 16]; Available from: URL: http://ncrb.gov.in/CD-CII2012/Statistics2012. pdf

4. Arulogun 0, Omotosho I, Titloye M. Experience of sexual harassment and coping strategies among students of the school of nursing of a tertiary hospital in Southwest Nigeria. [Online]. 2013. [cited on 2013 Oct 2]; 5(4): available from:URL:http://www.academicjournals.org /article/ article1379434109_Arulogun\%20et\%20al.pdf

5. Statistics. [Online]. 2009 [cited 2013 Aug 16]; Available from: URL: http:// www.rainn.org/statistics

6. Menon A, Shilalukey N. M .P, Siziya S, Ndubani P, M usepa M ,M alungo J, M unalula. B, M wela M, Serpell R. University students' perspective of create a secureenvironment for all.

It is found that the individuals of age group $12-34$ years are at the greatest risk of being sexually harassed which means that the students are at the greatest threat for being the victim. And when harassed sexually they may face adverse effects such as depression, anxiety disorder, substance abuse, low self-esteem, poor academic performance, etc. the students should have good knowledge about the preventive as well as corrective actions for sexual harassment. So this study enabled students to have an awareness on issues related to sexual harassment. A comprehensive training programme may help students to improve their abilities to deal with problems.

The study had following limitations, this study was conducted in few institutions, so the findings cannot be generalized to the population at large. The sample size was limited, also the sensitive nature study had some effect on the findings.

\section{Conclusion}

The present study could identify that the undergraduate students have knowledge on sexual harassment. The study was limited to the assessment of knowledge and was conducted among eight institutions. There are very less studies done on this area, hence more studies need to be done to assess the students level of awareness regarding sexual harassment so that proper interventions can be implemented.

sexual harassment: a case study of the University of Zambia. M edical journal of Zambia [online] 2009 [cited on 2013 Sept 10];36(2):Availablefrom: URL:http://www.google.co.in/url?sa= $\mathrm{t} \& \mathrm{rct}=\mathrm{j} \& \mathrm{q}=\& \mathrm{esrc}=\mathrm{s} \& \mathrm{frm}=1 \&$ source $=\mathrm{we}$ eb $\& \mathrm{~cd}=1 \& \mathrm{ved}=$ oCCkQFjAA\&url= http\%3A\%2F\%2Fwww.ajol.info\%2Findex.php\% $2 \mathrm{Fmjz} \% 2$ Farticle\%2 Fdownload\% 2F56060\% 2F44515\&ei=UyUzUtGPOc6lr Ae9ioHgAw\&usg=AFQjCNF2jz1k GTtEx6kWh66zwF3PfWqDzA

7. Abeywardene A., Atukorale S., Abeynayaka K., \& Thamara Athauda. A study on knowledge and prevalence of sexual harassment and abuse among schoolboys in Colombo District. Sri Lanka Journal of Chilf health. [Online]. 2004. [cited on 2013 Sept10];33: 9-17: available from: URL:http://www.sljol.info/index.php/SLJCH/article/view/ $661 / 642$

8. Johannes A., Gandhi N. A study on sexual harassment in colleges in Mumbai. [Online]. 2006 Oct. [cited on 2013 Oct 2]. Available from: URL: http://arajohannes.wordpress.com/writing/research/a-studyon-sexual-harassment-in-colleges-in-mumbai-an-excutive-summary/ 
9. Susan K., James H., Jodi S., Sherry A., \& Suzanne C. High school students' perceptions of nonconsensual sexual activity. J Sch Health. [Online]. 1995. [cited on 2013 Oct11];65(3):Availabefrom: URL:http://www.eoc.org.hk/EOC/Upload/ResearchReport/SH_eFull Report.pdf

10. Huges B, Hawkens E. Zero tolerance: experiences of, and attitudes to, sexual harassment at the University of York. [Online]. 2013. [cited on
2013 Oct 15]; available from: URL:http://www.yusu.org/docs / research/2013/Zero-Tolerance-Report.pdf

11. Tang C, Yik M , Cheung F, Choi, P., \& Au, K. Sexual harassment of Chinese college students. Archives of sexual behavior. [Online]. 1996. [cited on 2013 Aug 22]; 25(2): Available from: URL: http://link.springer.com /article/10.1007/BF02437936 